\title{
Pow(d)er to the People? Voter Manipulation, Legitimacy, and the Relevance of Moral Psychology for Democratic Theory
}

\author{
Norbert Paulo • Christoph Bublitz
}

Received: 27 March 2016 / Accepted: 30 May 2016/Published online: 17 June 2016

(C) The Author(s) 2016. This article is published with open access at Springerlink.com

\begin{abstract}
What should we do if climate change or global injustice require radical policy changes not supported by the majority of citizens? And what if science shows that the lacking support is largely due to shortcomings in citizens' individual psychology such as cognitive biases that lead to temporal and geographical parochialism? Could then a plausible case for enhancing the morality of the electorate - even against their will -be made? But can a democratic government manipulate the will of the people without losing democratic legitimacy? This paper explores the problems that governmental manipulation of voters pose for democratic legitimacy and the tensions between non-manipulated input and morally acceptable output. These venerable issues of political theory resurface in light of recent suggestions to tackle today's global mega-problems by Ingmar Persson and Julian Savulescu. They suggest that to avert the looming catastrophe, governments should alter psychological traits of the citizenry through biomedical means, from pharmaceuticals to genetics. However, we argue that a government cannot rule with democratic legitimacy if elected by a will of the people it manipulated before. Normatively, conferring power from the governed onto governors is a onedirectional relation that is incompatible with manipulation.
\end{abstract}

\footnotetext{
N. Paulo $(\bowtie)$

Department of Social Sciences and Economics, University of

Salzburg, Churfuerststr. 1, 5020 Salzburg, Austria

e-mail: norbert.paulo@sbg.ac.at

C. Bublitz

Faculty of Law, University of Hamburg, Rothenbaumchaussee 33, 20148 Hamburg, Germany
}

But while it is tempting to rebut suggestions to morally enhance the people as antithetical to essential ideas of democracy, swift rebuttals tend to overlook the deeper challenge: Majoritarian decision-making may lead to inacceptable outcomes. The dilemma between input and output runs through major works in political theory. Rather than wishfully ignoring the dangers of democracy, democratic theory has to provide answers.

Keywords Manipulation - Moral enhancement . Democracy $\cdot$ Indoctrination $\cdot$ Moral psychology

\section{Introduction}

Psychology has provided ample evidence that human decision-making is prone to distorting factors such as unconscious biases. Some of these cognitive and emotional deficiencies can affect moral and political decisions. For instance, because negative long term effects of actions (and omissions) are systematically and disproportionately discounted, humans are prone to temporal parochialism. Further, solidarity and altruism are often only extended to people near to us, to "in-groups", but not to "out-groups" who are more likely discriminated against-geographical parochialism. Ingmar Persson and Julian Savulescu relate such individual shortcomings to large scale political problems [1, 2, 3, also see the other papers in this issue]. They argue that the structure of global problems bears striking resemblance to deficits in individual minds. The devastating effects of climate change, for example, will only emerge 
in decades but have to be averted today. The inaction in face of a looming catastrophe could be due to the systematic discounting of long term effects. Likewise, poverty and starvation in the so called Third World could be averted or mitigated by modest efforts of the Western world. Nonetheless, such policies do not find a majority in western parliaments.

A democratic political order might increase the problem exponentially: if psychological deficiencies befall a majority of the electorate, majoritarian rule will likely let their consequences prevail over more reasonable views. Assuming that individual psychology indeed explains a considerable portion of voting behavior and, likewise, the inability of democracies to tackle pressing political problems on a global scale, Persson and Savulescu propose an intriguing solution: Governments should alter psychological traits of citizens, enhancing the psychological conditio humana, and remedying cognitive and emotional shortcomings on a society-wide scale through (not yet available) biomedical or neurophysiological means such as psychotropics, electric or magnetic brain stimulation, and genetics. A different mindset of the electorate may afford the implementation of urgently needed drastic yet unpopular policies.

Notably, Persson and Savulescu do not wish to abandon democracy in favor of more authoritarian regimes, even though it seems "easier for authoritarian political systems to implement unpopular policies than ... for democracies." They only seek to underscore the weaknesses of democracies to tackle problems that require unpopular solutions:

As history has shown with frightful clarity, authoritarian regimes can go disastrously wrong in ways that to this day no democracy has done, precisely because of this capacity to implement unpopular policies, which often promote only the interests of the ruling class. In our view, the solution to the mega-problems of today, if there is one, lies not in a shift to an authoritarian type government, but in moral enhancement of the citizens in democracies. $[1$, p. 8$]$

Thus, they propose moral enhancement of the electorate as a democratic solution. This suggestion inspires our inquiry. We suppose that governmental programs to significantly alter citizens' moral properties imply a shift to authoritarianism because the manipulative alteration of citizens' voting behavior is antithetical to democracy.
At least, governmental use of moral enhancements to modulate political decision-making of voters (without their consent) and, therewith, electoral outcomes poses intriguing problems for democratic theory. In particular, the legitimacy of a government is cast in shadows if it is elected after it manipulatively altered citizens' opinions and if the alteration caused the electoral outcome, i.e. if voters would have voted differently without the alteration. In that case, we suggest that government lacks legitimacy even though it was elected by a majority and all further conditions of a fair election were observed.

Persson and Savulescu address the problem of legitimacy only in passing, and although we will loosely come back to their work, we wish to engage with the problem of severe voter manipulation in more abstract terms. It is an intriguing issue that cuts to the bone of democratic theory, but is rarely pursued because discussions are caught up in empirical and normative controversies about what constitutes manipulation (e.g., campaigning, agenda setting). State-run moral enhancement programs provide an instructive test case to discuss normative ramifications of manipulation because, so we suggest, they qualify as severely manipulative. Persson and Savulescu's suggestions are instructive for another reason: They highlight an issue that requires more attention from political philosophy: the political relevance of moral psychology. What if it could be shown that voter decision-making is prone to systematic biases and distortions, and what if a reasonable case can be made that these psychological patterns are mirrored in the structure of problems such as climate change or global injustice? What if democracy is only viable or sustainable with citizens who possess specific moral views or moral capacities - and what if they lack them? How could we reconcile democratic ideals with evidence of moral incompetence in voters?

This paper seeks to explore this tension between democratically illicit manipulation and the possibility that democratic outcomes might yield catastrophic outcomes. In the following section, we will make the case for the incompatibility of severe voter manipulation and democracy. However, we will then argue (in the section "Democracy's dilemma: The perils of popular power") that quickly dismissing calls for mandatory moral enhancements might be tempting but tends to overlook the key problem, the other side of the tension, which provides the real challenge for democratic theories: they have to take the possibility of failure seriously. Failure, that is, not because of internal instability, but because decision-making procedures may lead to inacceptable outcomes. Taking serious indications 
that such outcomes are traceable to the psychology of the voters, the proposal to democratically enhance the electorate might not be a contradiction in terms, but rather a viable strategy to create suitable preconditions for democracy. Or so it may seem. The tension between the democratic requirement to not manipulate the input and the demand of acceptable output touches upon the ground layers of political theory. We suppose that severely manipulating voters cannot be reconciled with democracy. However, in the final section ("Democratic perspectives and solutions") we will sketch other ways to address climate change and global injustice. Although they require drastic changes to the current political order, they are genuinely democratic. For this reason alone, they should take priority over moral bioenhancements.

\section{Does Manipulation Undermine Legitimacy?}

In the history of ideas, the suggestion to make citizens morally more favorable inevitably reminds of a guiding motif of communism, the creation of a "new man." The utopia of truly free and equal persons requires for humankind to overcome animalistic drives, selfishness and antisocial tendencies. Only the communist explanation for humanity's darker side differs from Persson and Savulescu's view: for communists, social existence determines consciousness, not neurobiological or psychological shortcomings. Inner liberation follows outer liberation, whereas the neuroscientific zeitgeist reverses this relation. Trotsky foreshadowed this: "purely physiological life will become subject to collective experiments" [quoted in 4, p. 43], and it is said that Stalin's favorite metaphor for artists and educators was "engineers of the human soul" [quoted after 5, p. 23]. Just like contemporary transhumanists, communists suppose that the fate of humankind depends on transforming human nature. Among the reasons for communism's historical failure is that its attempts to reshape humanity never succeeded and sometimes turned into murderous disaster. Surely, no one proposes to revitalize communist re-education programs. But the striking resemblances between the bygone utopia and futuristic transhumanists visions cannot and should not pass unmentioned, particularly because western democracies countered communist aspirations of social engineering with pathos-laden proclamations of individual liberty and dignity. Normative individualism, the linchpin of liberal democracies, seemingly leaves no room for molding persons into politically favorably minded citizens. It is no coincidence that one of the inaugural works of modern democracy, Jean-Jacques Rousseau's The Social Contract, famously begins with an outline of the key task of political philosophy: to inquire the legitimacy of government "taking men as they are and laws as they can be made to be" [6, p. 155]. This illustrates a tension: taking people as they are is a cornerstone of democratic thought - moral enhancement encapsulates the idea of turning people into what they can be made to be.

Our guiding question is this: Does an elected government rule legitimately (in a democratic sense of the term) if it severely manipulated the will of the people in its favor prior to the election and if voters had voted otherwise without manipulation? We argue that it does not; it lacks democratic legitimacy. While this might appear self-evident, it is anything but agreed on in political theory. In a recent survey article James Fishkin writes, from "the standpoint of democratic theory, what, if anything, is wrong with manipulation ...? The answer depends on your theory of democracy. On some theories, there are no grounds for objections" [7, p. 34].We wish to go further and argue that irrespective of particular models of democracy, basic considerations of the relation between government and citizens speak against the possibility of a democratically legitimate government elected by a will of the people it manipulated before.

\section{Manipulation}

The implications of manipulation for legitimacy are not often discussed because the problems with defining what constitutes manipulation stand in the foreground. As often lamented, the concept of manipulation escapes a precise definition (see [8-11]; and from a political point of view [7, 12-14]). We cannot engage with the many proposed accounts here, and fortunately, we do not have to subscribe to a specific position or provide a sharp definition ourselves. A rough approximation suffices: We understand manipulation as the prima facie condemnatory sub-forms of influence that are usually impermissible and face a high burden of justification. Influence (on voters) can be exerted via manifold means and to different degrees, from communicative information and rhetoric over mass media advertisements and propaganda to the exploitation of psychological weaknesses, subliminal priming, etc. Some forms might be permissible, others outright illicit. The borderline where permissible influence turns into illicit manipulation is hard to pin down 
precisely. For the purposes of this paper it suffices to stipulate that we conceive of manipulation as influence that (at least) one person exhibits over another and that alters choices, opinions or beliefs of the targeted person in a way that she does not approve of, and that does not correspond to the demands of rational thought, [cf. 15, p. 31]. In addition, manipulation involves a form of control of the manipulator because the influence undermines or bypasses control capacities of the manipulated.

We are aware that this is not a comprehensive, clearcut definition. It neither captures all cases, nor is it finegrained enough to solve borderline cases; it also fails to adequately account for the role of emotions. Emotions surely play a larger role in deliberation and (political) decision-making than rationalistic philosophy and our understanding of manipulation suggest. Many successful and prima facie innocuous ways to influence others involve emotional influence that undermines control capacities (recall when you fell in love last time). Assessing the proper role of emotions is one of the key problems for a complete theory of manipulation. However, such a grand theory of manipulation is unnecessary for present purposes. Two rather weak claims suffice: Instances of illicit manipulation exist; and exposing others involuntarily to moral bioenhancements falls into this category.

With respect to particular interventions, much will depend on their severity. Current debates on moral enhancement focus on modest forms, [cf. 16, 17]. Consider a Veggie Pill that helps you resist the temptations you feel when ordering lunch. You like the taste of meat, but you also think that it is morally wrong to eat it. The Veggie Pill would support you to overcome your weak will and to do what you think you should do, i.e. not eating meat. You simply take a pill just before lunch. Assume it does not have severe effects on your autonomy or personality and that its effects wear off after one hour. Such individual and voluntary enhancements with minor short-term effects are, we contend, hardly problematic. A Veggie Pill even seems desirable. Although vegetarianism helps solving ecological and food availability problems, such limited enhancements are insufficient to resolve the "mega-problems of today." Overcoming the consequences of psychological deficiencies in voters requires far more severe, long-term and, most worryingly, involuntary alterations of moral capacities and beliefs on a population wide scale. ${ }^{1}$

\footnotetext{
${ }^{1}$ Cf. the paper by Schlag and the reply by Persson \& Savulescu, both in this volume.
}

The kind of moral bioenhancements we (and Persson and Savulescu) have in mind are, e.g. psychopharmaceuticals that alter one's moral proclivities and opinions, that modify selfish personality traits, eliminate morally relevant biases, amplify solidarity with outgroups or strengthen our "sense of justice". We further assume that they have to be given involuntarily because citizens do not consider themselves in need of moral enhancements. Assessing such interventions seems rather easy: If there are any instances of illicit manipulations, intervening into brains, altering neurophysiological parameters of a person (without consent) seems one of its paradigmatic forms. It is a far cry from skilled rhetoric, it has abandoned communication in any meaningful sense altogether [18]. These interventions do not provide arguments, but work directly on biological properties of the brain. They bypass the sphere of reasons, and therewith, the rational faculties and control capacities of the target. Altering the way a person thinks and feels through modulating the neuronal configuration that underlies such higher level mental processes and states is, to us, a clear case of tinkering with another's mind in a prima facie impermissible way. If there is a moral duty to not manipulate others, refraining from secretly or coercively accessing her opinions on the neural level seems to be among the first demands. Any theory of manipulation that is unable to capture such interventions would be unpersuasive. Thus, even without drawing the borderline more precisely, we are confident that mandatory moral enhancements in the form envisioned by Persson and Savulescu fall on the illegitimate side of it. ${ }^{2}$

What rather has to be shown is that there is a duty to not manipulate others. In light of the value of autonomy, we do not have any hesitation to assume a right against being manipulated on the individual level (one of us argued elsewhere that severe forms should constitute a criminal offence [19]). Altering moral beliefs or political opinions through brain interventions also likely violates the human right to freedom of thought and conscience. But here, we are interested in the collective level, in the political consequences of manipulation. The suggestion is that the demands of democratic legitimacy imply a prohibition of government to manipulate voters. We stress these points because a usual response to our following claims is an argument about the precise limits of permissible governmental influence. Of course, all

\footnotetext{
${ }^{2}$ Later in this paper we will discuss less drastic forms of illicit governmental manipulation.
} 
governments somehow influence citizens' moral dispositions, from civic school education or public broadcasting services to pledges of allegiance and patriotic spectacles. Every collective influences its member, and social psychology is ubiquitous. But be this as it may. Taking a critical stance towards paradigmatic cases of manipulation does not require drawing borderlines more concretely.

\section{Legitimacy}

Legitimacy of state power is the central problem of political philosophy - where does the power to rule originate from, what sets legitimate rule apart from the mere exercise of factual power? Although democracy might well be an essentially contested concept and even though dictatorships notoriously embraced the term, we suppose that democracy answers these questions in a distinct manner: The characteristic feature of democracy is popular sovereignty, that is, the collective self-rule of free and equal citizens. Governmental legitimacy derives from the will of the people. And the will of the people, in turn, emerges from the wills of individual citizens. The ultimate source of governmental legitimacy lies in the political opinions and preferences of the citizens. These opinions and preferences are, in the form of votes, the input into the democratic system. Democratically legitimate governmental authority is essentially grounded in this dimension; input legitimacy is a necessary element of democratic rule.

Of course, this input element might not suffice for legitimacy. Many democratic models require additional output constraints, such as observing minority rights, furthering the common good or even global justice. Democratic models regularly seek to achieve or secure desirable outputs by designing institutions that restrict majoritarian input powers (such as constitutional rights and judicial review). Furthermore, there may be other forms of legitimate political authority. They might be legitimate because they produce desirable outputs (e.g., governance by not elected international organizations). But if they derive legitimacy from outputs only (rather than from the will of the people), they lack democratic input legitimation. The question before us is then whether governments can manipulate the input dimension, the will of the people, to secure proper outputs, without falling into this latter category. Let us look at this in some detail.
Simple Formal Theories: Aggregation of Preferences

A basal understanding of democracy can be summarized as the correct aggregation of the preferences of the people under a simple idea of equality such as "one man, one vote." Government truly reflects the will of the people if and only if majoritarian preferences prevail. In other words: there has to be a correspondence relation between the will of the people, the outcome of an electoral process, the composition of the elected representative legislative body (parliament), and government. This correspondence relation is a minimum requirement, beyond dispute in principle, although mitigated in practice. The correspondence requirement does not extend to each and every political decision. Once elected, representative governments are not bound by the will of the people in every single decision they make. Leeway to deviate from the general will is what sets representative forms apart from direct democracies. It is one of the central arguments against direct models that ordinary voters might not fully oversee the complexities and consequences of politics and that the will of the people is better mediated by a layer of experts and parliamentary processes. However, the possibility to depart from public opinion in particular decisions does not call the correspondence requirement in question.

Simple aggregative models of democracy might not stipulate further demands. Whatever the preferences of the people - and however they came about—, as long as they are correctly registered and aggregated, the legitimacy conditions are met. As a consequence, such models might not explicitly object to manipulation of the electorate or call into question the legitimacy of the government elected after manipulation. However, these models may overlook a general argument against the compatibility of governmental legitimacy and manipulation which we will unpack in a minute.

Moreover, simple models are not particularly attractive from a normative perspective. Proponents such as Walter Lippmann or Joseph Schumpeter in fact subscribed to them because of their deep distrust against the capacity of ordinary voters. Uneducated, longing for easy answers, and susceptible to influence, the role of voters is restricted to choosing between competing elites. As Lippmann beautifully wrote about "ordinary minds":

In the uncriticized parts of the mind there is a vast amount of association by mere clang, contact, and succession. There are stray emotional attachments, 
there are words that were names and are masks. In dreams, reveries, and panic, we uncover some of the disorder, enough to see how the naive mind is composed, and how it behaves when not disciplined by wakeful effort and external resistance. We see that there is no more natural order than in a dusty old attic. There is often the same incongruity between fact, idea, and emotion as there might be in an opera house, if all the wardrobes were dumped in a heap and all the scores mixed up, so that Madame Butterfly in a Valkyr's dress waited lyrically for the return of Faust. [20, p. 405 f.]

Based on this pessimistic view Lippmann argues that only representative public officials - not individual citizens - have the time, training and knowledge to make informed decisions and advocates a kind of Socratic reeducation of the people [20, Ch. XXVII]. As a consequence, the input dimension - and thereby the importance of voters - is marginalized in favor of expert rule.

Such elitist models can be understood as answers to the problem of deficient input quality. Many objections have been raised against elitism, precisely because of its shallow level of citizen participation and its disregard for the input dimension. Even though many existing democracies may resemble elitist models, to critics they are democracies by appearance only. Correspondence may thus be a necessary but not a sufficient condition.

\section{"Free Formation" of the Will}

Most theories of democracy demand more: the will of the people has to be formed in certain ways, or negatively, it must not have been formed in ways flouting basic democratic ideals. Many models therefore require the free formation of the will, expressed, for instance, in the European Electoral Principles. The third principle, called "free suffrage", secures the "freedom of voters to form an opinion" [21, at 3.1.a]. A free and fair election ("free suffrage") is a precondition for the legitimate rule of the elected. Accordingly, governments cannot influence voting behavior without losing legitimacy. The notion of free suffrage needs further explication: What does "free" mean, and why is it a necessary condition of legitimate rule? The general idea is that the formation of the public will should be free from certain kinds of distorting, manipulating, autonomy undermining influences. A different formulation encapsulating the same idea might be instructive: A central tenet of classic democracy is that legitimacy of governments, or, in the words of one of the founding documents, the US Declaration of Independence, "just powers" derive "from the consent of the governed." In today's understanding, normatively relevant consent is informed consent, which places some qualifications on the way it has been brought about. ${ }^{3}$ Non-manipulation is one of them [22]. But as not every democratic theory accepts it as a necessary condition for legitimacy, we wish to develop an argument showing that the "free suffrage" principle is indeed essential to democracy by comparing voter manipulation with other forms of legitimacy undermining governmental conduct.

\section{Coercion}

Coercion is the easiest case. Formation of the will is not free if voters were coerced, e.g., by intimidating threats at the polling station. Irrespective of the finer details of the debate whether a coerced agent acts according to his preferences by giving in to a threat (she may, for instance, prefer her life over voting for her favorite party) $[23,24]$, coercion is a paradigm case of heteronomous influence that nullifies voluntariness. Because will formation was not free, government cannot derive legitimacy from the will of the people. Absence of coercion is thus a precondition for legitimacy conferring free elections.

\section{Deception}

A perhaps less obvious, but still clear case is intentional deception. Suppose a government wrongly informed the public on an important matter before an election in which it is re-elected. Suppose further that it had a legal duty to disclose the matter truthfully, and that the issue played a decisive role for voters (such as a drastic misstatement of unemployment figures or a Clintonesque affair in personalized elections). Many pro-government voters truthfully complain that they would not have voted the way they did had they known the relevant facts. Does the elected government rule legitimately? While it does represent the will of the people in the moment of the election, it is hard to deny

\footnotetext{
${ }^{3}$ Regarding informed consent, we wish to stress that votes do not have to be informed, just as medical decisions do not have to be. Many voters probably have no comprehension of the issues at stake. However, voters - and other decision-makers - must have the chance to be informed, relevant information must be available.
} 
that the will of the people was formed faultily because of the deception. Surely, politicians notoriously spin, bend and embellish facts before elections. Nonetheless, deceptions of some gravity violate a necessary condition of a free (and informed) formation of the will. As a consequence, government's legitimacy cannot be based on the election. It would be absurd if governments could ground their legitimacy in the will of the people it has deceptively influenced before.

The legitimacy problem might become clearer from a different angle. One could deny that the electoral outcome reflects the will of the people. Given their preferences, they would not have voted for the government if they had known the facts to which they were entitled. Their choice did thus not reflect their preferences in that objective situation, only those on the incorrect assumption of different conditions. One may argue that the correspondence requirement is not met and the electoral outcome does not reflect the "real" will of the people.

On the political level, access to truthful information then becomes a precondition of democratic legitimacy. For this reason, freedom of speech and freedom of press are conceived as political rights. Censoring opinions and facts not only violates the rights of censored speakers, but also undermines the will formation of the people. We suppose that most theories of democracy will agree that deception undermines legitimacy, albeit voting procedure and aggregation were performed correctly.

\section{Altering Short-Term Preferences}

A different kind of influence undermines free will formation in the next scenario. Suppose that opinions of voters are altered through some manipulative interference in the proximity of the polling booth, for instance, by rhetorically skilled agitators who exert systematic and severe emotional and situational pressure on voters. Imagine these influences are successful. Upon reflection and out of their reach, voters reassert their previous opinions. In that case, the free formation of the voter's will is undermined. To protect against such short-term opinion changes, many countries install safeguards: no political advertisements and campaigning at polling stations, no disclosure of estimates on Election Day (or several days before). The objective is, again, to avoid unwise voting decisions because of last-minute manipulative influences, lacking time to reflect, and to provide more favorable external conditions for freely forming one's opinion. The presence of such influences undermines a free and fair election.

This is even truer of biochemical manipulation. Imagine an odorless substance such as Oxytocin is sprayed in the polling booth and effectively alters voting behavior. Again, the will has not been formed freely. The outcome might correspond to the preferences of voters in the moment of voting. But these are not the real preferences, they are transiently manipulated ones. In analogy to Harry Frankfurt's famous distinction, one may speak of a conflict between situational first and longer-term second order political preferences. Elections are concerned with the latter. The polling booth is the symbol of the freedom of the vote-free from, e.g., influence, pressure, need of justifications, or potential repercussions.

\section{Paradox of Long-Term Preferences Manipulation}

The key question is whether that freedom should extend beyond the voting booth to the formation of the will in general. The moral enhancement programs Persson and Savulescu envision cause more permanent, durable transformation of preferences. They can be considered as extensions of transient manipulation. This leads to an argument a fortiori: If less invasive manipulation calls legitimacy into question, stronger ones do so all the more.

However, long term preference manipulation raises a well-known problem, the paradox of thorough manipulation. Imagine a sinister neuroscientist manages to replace the entire preference structure of a person. This surely constitutes manipulation, although, if successful and severe enough, the discrepancy between first and second order preferences vanishes. As a consequence, opinions have truly changed, and the post-manipulation person will argue and defend her novel views as her own, she might wholeheartedly identify with them. At some point, the manipulated will becomes the will of the manipulated person.

For our inquiry, this means that even if new elections were held, the result would not change. The elected government does represent the will of the people, the correspondence requirement obtains. The structure of the problem is familiar from the free-will debate [24-26]. But instead of engaging with this debate here, we offer a different argument that directly pertains to the idea of democracy. Even if one considers a thoroughly manipulated person free in regard to moral 
responsibility, we deny that her votes can confer legitimacy onto the manipulating government. The classic case is political indoctrination. Indoctrination runs counter to democratic ideals. However, we forsake from employing the term "indoctrination" for our purposes because its vagueness would further complicate matters. The reason why long-term alterations (and indoctrination) undermine legitimacy is that the election concerns and benefits the manipulator herself. Even if the manipulated person is to be considered responsible vis-à-vis third parties, she is not responsible vis-à-vis the manipulator with respect to the manipulated aspects. Manipulation creates a hierarchical relation of control between manipulator and manipulated. And as responsibility tracks control, the person who directs and steers a process, be it through natural forces or other persons, bears responsibility. Actions of the manipulated are ascribed to the manipulator. In a similar way as persons can act through (or mediated by) tools or technology, manipulators act through the manipulated. A capo controlling a gang never makes his hands dirty. But he cannot wash them in innocence. Actions of gang members are ascribed to him, they are his actions. Whether the subordinates are also responsible is irrelevant here. What matters is that a manipulator acts, normatively, through the manipulated. 4

In democratic terms, conferring legitimacy is a onedirectional, bottom-up relation: from citizens onto governments. It does not work conversely. If governments severely manipulate the will of individuals - and thereby, of the people as a whole - a circular relation ensues. Government is not representing the will of the people, but vice versa. To put it differently: Because acts of the manipulated are ascribed to the manipulator, a government manipulating voters would, in the end, elect itself. This cannot confer legitimacy. There is an asymmetry: The power of government has to derive from the will of people, but the will of the people cannot derive from the will of government. Governmental manipulation of the will of the people thus contradicts democratic essentials; it cannot ground legitimacy in the will it manipulated. Manipulation and legitimacy are incompatible. This general relation, we contend, applies to any democratic theory that recognizes the will of the people as the sole

\footnotetext{
${ }^{4}$ The following example might be helpful: If A manipulates B into harming $\mathrm{C}, \mathrm{C}$ might not only complain to $\mathrm{B}$ but also to A because she controlled B's actions. A, in turn, cannot complain over B's action, because she herself brought it about. A would have to complain to herself as B's act can be attributed to her.
}

source of legitimacy (and thus, even to simple aggregative models previously discussed). ${ }^{5}$ In the following section, we try to strengthen this rather abstract argument by discussing its place in several particular theories of democracy.

Supporting the Argument: Particular Accounts of Democracy

\section{"Liberal" Democracies: Rights as Constraints of Governmental Powers}

Although the term "liberal democracy" is not clearly defined, it summons the idea that public power is bound by pre-political rights which create a sphere of liberty, not subject to majoritarian decision-making. It comprises elements fundamental to the idea of free and equal citizens. John Rawls, for instance, enumerates a set of basic liberties in his Theory of Justice. One of them is the "right to freedom of conscience", which includes moral freedom. In fact, Rawls writes that "equal liberty of conscience is the only principle that the persons in the original position can acknowledge" [27, p. 207, emphasis added].

In this view, forming opinions and decisions freely is a guarantee that sets outer limits to governmental powers. A state-run moral enhancement program likely contravenes this liberal premise. One might dispute that freedom of conscience is a necessary element in a basic set of liberal rights. However, we suggest that this right is not just coincidentally included in many of such sets but that it is internally connected to the idea of democracy, so that its observance is a precondition of legitimacy.

\section{Value of Democracy: Brettschneider and Dworkin}

An argument for such a necessary connection can be found in Corey Brettschneider's "value theory of democracy." Among its central claims is that collective

\footnotetext{
${ }^{5}$ One might object that a government could be democratically empowered to use moral enhancements to change its people (just as individuals can bind themselves with Ulysses-style contracts). Such a collective decision might indeed not necessarily render the government illegitimate, but only if the decision is unanimous, which is hardly conceivable. As soon as there is a single dissenter, the majority decision would not be binding for her. Ulysses-style autonomy-waivers only work for the affected persons and cannot extend to the autonomy of others.
} 
democratic self-rule requires respecting every citizen as a self-ruler, which in turn preconditions respect for particular substantive democratic or political rights such as free speech and freedom of thought:

"Rights to express and to listen to ideas are justified by the more basic right of citizens to make up their own minds about politics" [28, p. 45]. Brettschneider asks his readers to imagine a situation relevantly similar to ours. What if it were predictable that citizens would vote for morally wrong options?

It is clear that any attempt to force citizens to vote a particular way would be a paradigmatic violation of the democratic right to freedom of conscience. The reasons why such a forced vote is unacceptable in a democracy are not merely instrumental; they go to the heart of what it means to treat citizens as sovereign. The ability to decide wrongly is itself a fundamental democratic right. In no sense can citizens be regarded as rulers if restrictions are placed on how they can think about politics, especially when it comes to how they vote. Freedom of conscience is essential to democracy - particularly to the core value of political autonomy- because it ensures that self-rulers will be able to think for themselves [28, p. 45].

Brettschneider's argument about forcing voters equally applies to manipulating them. Both disrespect the citizen as sovereign. In a similar vein, Ronald Dworkin contends that we do not value democracy as a function of majority rule [29, 30]. Dworkin's "partnership conception" of democracy [29, p. $382 \mathrm{ff}$.] requires, inter alia, that government leaves it to the individual how to think about politics and ethics. And because ethics and political philosophy go hand in hand, "endorsement [of an act or vote] must be genuine, and it is not genuine when someone is hypnotized or brainwashed or frightened into conversion. Endorsement is genuine only when it is itself the agent's performance, not the result of another person's thoughts being piped into his brain" [31, p. 269]. Dworkin and Brettschneider establish necessary links between political rights such as freedom of conscience and democratic political orders.

\section{Republican Models: Pettit}

The idea can also be found in republican models, the traditional counterpart to liberal approaches. Republican models do not cordon off basic rights from majoritarian decision-making in the more principled manner than liberal theories do. They allow — and demand — orientation of policies toward the common good. While liberal models stress interests and preferences of individuals, possibly pursuing self-centered goals and disinterested in others, republicans seek to strengthen the polity, active citizen participation in the political process and common understanding. Echoing a distinction by Jon Elster, one may say that liberals tend to equate elections and political will formation with markets whereas republicans are more interested in the forum.

In Philipp Pettit's version, the core of the republican tradition is "non-domination: the condition under which you live in the presence of other people but at the mercy of none" [32, p. 80]. The notion of non-domination is different from negative freedom, since "[w] $[\mathrm{w}$ hat constitutes domination is the fact that in some respect the power-bearer has the capacity to interfere arbitrarily, even if they are never going to do so" [32, p. 63]. Domination can thus occur without actual interference. One only lives "at the mercy of none" if no one has the capacity to interfere arbitrarily.

This understanding of republican liberty also implies certain basic structures in the relation between citizen and the state that reject manipulation of voters. As Pettit puts it:

The lesson is that the instruments used by the republican state should be, as far as possible, non-manipulable. .... No one individual or group should have discretion in how the instruments are used. No one should be able to take them into their own hands: not someone who is entirely beneficent and public-spirited, and certainly not someone who is liable to interfere for their own sectional ends in the lives of their fellow citizens. The institutions and initiatives involved should not allow of manipulation at anyone's individual whim [32, p. 173].

\section{Deliberative Models: Habermas}

The paradigm case against manipulation of will or voters comes from deliberative theories, e.g., in wake of the work of Jürgen Habermas. According to him, political decisions are legitimate if and only if they result from a specific process of decision-making, namely from a structured deliberative discourse. The procedure forms the basis of legitimacy. It implies public reasoning open to all citizens aiming at mutual understanding. It 
should take place in a neutral public sphere, preferably under ideal speech conditions which are characterized by equality, recognition of other viewpoints and the absence of power and might. In such conditions, "no force except that of the better argument is exercised" [33, p. 108, cf. 34]. The hope is that the deliberative decision-making process yields outcomes everyone has reasons to accept $[35,36]$. The better argument, then, is only identifiable through the proper procedure.

The task of the constitutional state is to establish the framework and suitable background conditions for deliberative discourse. Beside free press, this includes rights against manipulative influences on political will formation. Surely, as its name suggests, such speech situations are ideal and, just as free deliberation among equal citizens, probably never fully attainable. But they serve as regulative ideals which can be approximated. Indoctrination or tampering with others' emotions or neuronal structures is diametrically opposed to these requirements. Moral enhancement substitute the force of the better argument with the force of pharmacology. Mandatory enhancements are a paradigmatic form of overwhelming power. And they bypass the "sphere of reasons" altogether and work on the biochemical level alone. Any theory inspired by deliberative ideals must reject moral enhancement programs.

\section{Equal Influence on Public Opinion}

A final element inherent to democracy should briefly be mentioned: equality. But equality of what? While the "one man - one vote" scheme which accords the same voting power to the uneducated as to the Nobel laureate is an indispensable part of contemporary democracies, one might make the case that democracy requires more. If one takes serious the idea of an association of free and equal citizens who jointly reason about the common good, equality might need to expand to "having an equal say" before the ballot is cast. Citizens should have equal opportunities to present their views and persuade others in the struggle of political ideas. Equality of influence then becomes a further distinct element of democracy.

Today's real political conditions are marked by stark inequalities of influence, aptly proven by the importance of campaign financing. Due to lacking access to mass media, the voices of many, particularly marginalized populations, are not heard by the public at large. This is a serious shortcoming of the current state of democracy. It would be exacerbated if some groups have novel means to change public opinion such as moral enhancements at their disposal. In terms of equality, these means have to be available to everyone participating in the forum.

To summarize: The foregoing theories, and therewith, most contemporary accounts of democracy, reject the manipulation of the will formation of the electorate through biochemical means because it runs contrary to central ideas of democracy. Democratic legitimacy necessitates a strong input-element. But the will of the people cannot confer legitimacy if it was manipulated. Thus, the right to remain free from such influences on political opinion formation is a necessary political right, just like the right to vote or freedom of the press. Interferences with the free formation of the will of the people undermine the legitimacy of the government. Even though it was elected, it lacks a necessary element of justification, namely, input-legitimacy. The political system Persson and Savulescu hint at would be a pseudo-democracy, populated by institutions, elements and procedures typical for democracies, but hollow inside, void of the legitimacy conferring element.

\section{Democracy's Dilemma: The Perils of Popular Power}

It might be tempting to end at this point and dismiss Persson and Savulescu's suggestions as contrary to essential democratic ideas. But that would be too simple. The tension between input and acceptable output is a key problem for democratic theory too often neglected or even pretentiously rejected. It is a challenge that has to be taken seriously because it imperils the plausibility of the democratic project at its heart. Democracies are not a priori immune from the danger of insufficient input. History shows that the will of the majority can go disastrously wrong. Many unacceptable outputs are preempted by majoritarian constraints. But not all of them: Climate change and global injustice are evident examples in which usual safeguards - in their current form - fail. Input problems have occupied democratic theorists ever since. In this section, we show that, somewhat surprisingly, many democratic theories presuppose transforming political preferences and creating democratic citizens.

Let us assume, arguendo, that democracies might produce bad, even outright morally unjust outcomes because they amplify problematic tendencies of human psychology. This puts the spot on one of the notorious Achilles' heels of democracy: its outcome depends on inputs of contingent quality (colloquially, a garbage in - garbage 
out problem). Consequently, the idea of failure has to be taken seriously. Positive outcomes appear to require distinct psychological capacities of voters (just as they may require favorable social conditions). Simply assuming that citizens possess these qualities would be naïve, especially in light of psychological findings to the contrary.

\section{How Democracy can fail}

At this point, we need to briefly explain in which sense democracies can fail. How, adherents of inputdemocracies may object, is it even possible that democracy leads to erroneous output? Such a contention presupposes a yardstick, an independent standard, against which outcomes can be measured. Input-accounts may conceive this as misleading; there are no failure conditions built into democratic theory. The decision brought about through the right procedure is the democratically correct result. Input legitimizes output. Evaluating results in light of standards not themselves generated through democratic procedures is, ultimately, anti-democratic. It makes the correctness of democratic decisions contingent upon conformity with a non-democratic standard.

Indeed, external standards are hard to justify by principles of input-democracy alone. However, and here lies the catch which input-theories have to acknowledge, at least in principle: What if a strong argument in favor of a basic set of substantive political goals can be made? Proponents of moral enhancement, for instance, resort to goals no less significant than the survival of humankind in face of weapons of mass destruction, minimal standards of global justice (e.g., tackling easily preventable deaths due to malnutrition and lacking access to health care), and the aversion of grave effects of climate change. These goals, we believe, are hardly contestable from a moral point of view. Any democratic theory that does not accord them heightened importance is impoverished to the extent that its justification loses plausibility. These are not just goals one may espouse or reject. Rather, they are, in Rawlsian terms, part of the overlapping consensus of reasonable comprehensive moral doctrines. While one may argue about details, there does not seem to be reasonable disagreement as to the fact that these are important goals, nor that current domestic and international politics systematically fail to address them in a satisfying manner. If that is the case, the issue before us is not merely a variant of the familiar quarrels over liberal state neutrality vs. value oriented policies. Rather, it touches upon the more existential question whether democracies can fail to deliver outputs necessary under all reasonable moral theories.

Strong input-theories are committed to value the pursuit of these goals only if the popular will tells so. But that is a weak and potentially fatal line of response. The persuasiveness of input democracies pales in light of the moral importance of these goals. We have to acknowledge the possibility that the popular will can err. Although this is a serious concession, input-theories have to be amended with output-constraints. And, in fact, hardly any democratic theory does without some output correction.

Most existing democratic systems impose constraints on public power in the form of negative constraints, e.g. constitutional rights. However, restricting the scope of public power may not suffice to solve present problems because coordinated, large scale positive state action is required to address global injustice or further a carbonless industry. And the bleak implication of our assumption is that governments that pursue such necessary but unpopular policies will not be re-elected. Simply constraining public power does not suffice; positive action in the right direction has to be taken.

Against this backdrop, modifying the input dimension seems a viable proposal. We have already encountered one such strategy, Schumpeterian elitist democracy: marginalize the weak element, the role of voters, and leave the rest to professionals. But this already comes close to conceding defeat for democracy. At best, it is "democracy light", without guarantee of a happy end. Real world politics demonstrate that elitist and expert democracies do not necessarily further the common good.

A better alternative might indeed lie in improving input, just as proponents of state-directed moral enhancement suggest. Flourishing democracies cannot be founded, as Kant wrote, by a "nation of devils". Democracies need democrats, homo democraticus, whose interests reach beyond immediate self-related ones. Democracy is only as good as the people it engages. In fact, the need to make citizens better, suitable for democracy, and the dangers of giving the masses too much power have been recognized by democratic thinkers ever since.

\section{Creating Citoyens}

Let us return to Rousseau. Fully aware that the will of the people in the form of aggregated individual wills, the volonté de tous, does not correspond to the public interest, the volonté générale, he made two suggestions: In 
clear contrast to the opening statement of The Social Contract, quoted above, he fiercely advocated reforming the human character and creating citizens as laid out in his novel Emile, often considered the inception of modern educational theory. On the political level, Rousseau introduced the-quasi-religious and somewhat dark-figure of the lawgiver. His task is to convince alienated, hostile, and vicious people to engage in a ground-shifting venture, namely to waive their natural rights in order to conclude the social contract, in short, ending their bourgeois existence and becoming citoyens. The lawgiver has to be an "educator" and a "leader," someone with a "great soul" and "true virtue" in order to overcome human degeneration. He should be

capable, as it were, of changing human nature; of transforming every individual, who in himself is a complete and independent whole, into part of a greater whole, from which he receives in some manner his life and his being; of altering man's constitution in order to strengthen it; of substituting a social and moral existence for the independent and physical existence which we have all received from nature. In a word, it is necessary to deprive man of his native powers in order to endow him with some which are alien to him, and of which he cannot make use without the aid of other people [6, p. 181].

Because of his proposal to radically alter human nature in the name of the common good, Rousseau is often suspected as anti-democratic. But the tension between individual interests and the common good is not a peculiarity of Rousseau's work. It marks a basic tension within democratic theory. Even though it has not escaped notice by democratic theories, it is rarely given center stage.

Some, such as John Stuart Mill, sought to alter the input dimension by denying equal input, giving the well-educated and more competent citizens greater voting powers - surely no promising answer in light of today's democratic standards. Other thinkers tacitly dwell on optimism, often founded in the - widely supposed-transformative power of democratic politics. Democracy has beneficial impact on the character of citizens, e.g., because of the constant need for public justification. Yet, these effects are apparently not enough to form democratic characters of a quality guaranteeing good outcomes.
Other theorists who are aware of the problem that untutored preferences may result in inacceptable democratic outcomes present different strategies: Pettit suggests to take particular questions where "popular passion" reigns and leads to inacceptable outcomes out of democratic control in order to "depoliticize democracy" [37]. This is a serious concession. Michael Sandel's republicanism, by contrast, rejects the idea to take "people's existing preferences, whatever they may be, and $\operatorname{tr}[\mathrm{y}]$ to satisfy them." Rather, in line with the classic Greek political tradition and not unlike Rousseau, it "requires that citizens possess, or come to acquire, certain qualities of character, or civic virtues" [38, p. 5 f.]. Republicanism is "a formative politics, a politics that cultivates in citizens the qualities that selfgovernment requires." "Moral character", he writes, "is a public, not merely a private, concern" [38, p. 25].

John Rawls addresses the problem from a different angle. For one, he bypasses it by stipulation. In his $A$ Theory of Justice, citizens are devoid of a rich and problematic psychology. Although mutually disinterested, they possess a sense of justice. Furthermore, a lot of work in Rawls's account is done by the notion of public reason and restrictions of which reasons count as permissible. Deliberating upon the essential framework of a just society, citizens have a civic duty to only present a special set of reasons, public reasons, potentially acceptable to anyone. To him, "voting is not a private and personal matter" [39]. Not because the public is allowed to alter or manipulate votes, but because voters have the duty to curtail their own reasoning and will formation. The public reason requirement thus ensures from the very beginning that self-regarding or anti-social preferences cannot prevail in the democratic procedure.

Deliberative theories place their hopes in collective rationality. The initial preferences with which individuals enter deliberations are transformed and refined though the inherent powers of reason, as engendered in rational discourse. Non-universalizable and merely self-regarding interests are cancelled out in the process. The procedure transforms preferences, leading tohopefully widely agreeable - rational outcomes. The quintessence of deliberativism is overcoming initial individual preferences in search of the common good though discourse.

These examples show, perhaps surprisingly, that many democratic theories presuppose that citizens' preferences have to be transformed and that justifiable democratic outcomes may require creating democratic 
citizens. The widely criticized communist idea of remolding humankind can, in fact, be traced to the inceptive period of modern democracy - Enlightenment. The new "sciences of men"- and the often materialistic view - afforded to link the human condition to social, political and economic circumstances and thereby provided the opportunity for reform [5, Ch. 2]. Rousseau is a focal point of two diverging trajectories in the history of ideas: the liberal democratic tradition and the communist creation of "new man", both merely emphasizing different aspects. These trajectories also mirror the previously mentioned tension within democratic theory: Some-especially simple liberal aggregative models - take preferences as they are; others are more demanding and imply preference transformation through refashioning citizens' moral character, restricting the set of relevant reason, or through the rationality filter of collective deliberation. The former theories fall prey to outcome based objections such as those of Persson and Savulescu. Perhaps, then, moral enhancement should be understood as a continuation of the transformative projects of the latter theories with different means. If democratic societies must inculcate their values in citizens, and if given preferences cannot therefore be declared sacrosanct, moral enhancement might be a novel way to secure democracy's very foundations. Rather than opposing the democratic project, it furthers widely endorsed aims.

Since skepticism about deliberative politics is warranted, moral enhancement might even be the more feasible option [40, p. 24]. Deliberativism's ideal conditions will never be approximable, let alone attainable, in modern states comprising millions of citizen. And even if they were, whether rational discourse does possess the transformative powers ascribed to it remains an open, empirical, question. Arguments in the line of Persson and Savulescu are much closer to psychological realities than a Habermasian vision of discourse so abstract that it cancels out the person and its pathologies altogether in the idea of a "subjectless discourse." Deliberative theories, desirable as they may be, are rather a thought experiment that helps to justify state authority in ideal worlds, but do not provide feasible real world options.

We have thus the suspicion that many democratic theories do not address the problem adequately because they do not pay close attention to individual persons and their psychological dispositions. Even though the claim that bad societies produce bad citizens sounds like a platitude, the problem is still alive and pressing. Moral psychology puts the task for democratic theory right on the table: High theory has to meet ordinary individuals [see, e.g., 41]. A convincing theory of democracy has to take psychological deficiencies serious and cannot dwell in idealized assumption and wishful thinking. In face of such considerations, moral enhancement may appear as a realpolitikal solution to a repressed problem.

\section{Critical Assessment}

However, the fact that theorists have acknowledged the problem and accommodated it in theories merely marks the problem, but it does not soothe the inner tension between preference engineering and democracy. Sandel's formative project, for instance, is under criticism precisely for its anti-democratic tendencies [42]. The governmental aim of bending the views of those who confer power onto them in its favor cannot easily be reconciled with democratic legitimacy. Further lines have to be drawn. In general, the aim to influence thoughts and opinions might not undermine legitimacy across the board because some means are more in line with democratic ideals than others: The means matter, and so do degrees.

First, one should not analogize civic education of children and moral enhancement of the general populace [43]. The normative relation between parents and the state vis-à-vis children (and their future) who do not yet have a fully developed preference structure and opinion forming capacities is too dissimilar to the relation between government and citizens as bearers of political power. Democratic education raises problems for democratic legitimacy on its own [44], but the transformative project would be much less worrisome if it only entailed education of children (as, e.g., suggested by Rousseau).

Second, democratic ideals are more hospitable to certain methods: first and foremost, argument, discourse, and rational persuasion. Hearts and minds of voters have to be won with ideas. Irrespective of particular theories, the proper mode of democratic will formation is rational argument. If political opinions are altered by the force of the better argument, democracy is not undermined, even if government is involved in the communicative process. Democracy is a collaborative project playing in the space of reason. And if voters suffer from shortcomings in reasoning, they have to be persuaded that they do so and motivated to overcome them through voluntary means (which can include moral enhancements). 
Our insistence on the idea that only some means to change minds are consistent with democracy is not, as sometimes suggested, contradicted by the fact that all will formation is influenced and that preferences can change non-rationally. People may, for instance, unconsciously adapt their preferences to what they can reasonably expect to attain ("sour grapes"). Sandel mocks the "spectacle of 'free men' going to the polls" as illusionary [38, p. 204]. However, democratic legitimacy does not presuppose fully independent, unencumbered selves. Opinions are never formed freely, in the sense of free from any external influence. On the contrary, influence is ubiquitous, and everyone who forms her opinion in exchange with others is subject to introspectively unaware influences. But this does not necessarily render her will formation unfree. The fact that many preferences and opinions are formed by unconscious influences does not render all distinctions meaningless. Considering argument as the proper mode of democratic preference transformation does not imply that strongly biased and emotionally laden political campaigns are beyond scrutiny (think about current campaigns in Europe and the US that appeal to deep seated fears of "invasion" by foreigners). But if they accompany substantive arguments, such emotional campaigns are less clearly manipulative than direct brain interventions.

Whoever wishes to object to this distinction between free and unfree formation in principle (rather than to mere demarcations) would have to assert that illicit manipulation does not exist at all, for instance, because all means to alter another's minds are normatively on a par [45]. In this context, parity is an unfeasible claim because it negates the very possibility to identify blameworthy psychological trickery (such as brainwashing or indoctrination). So, we suggest that although its contours are amorphous, illicit manipulative influence on the will formation of others is a real phenomenon, and that biochemical means of moral enhancement are instances of it. ${ }^{6}$

Imagine the normative consequences: If moral enhancement were a permissible way to alter voters' opinions, then less invasive and less powerful means would be all the more. Why then, for instance, should governments not indoctrinate and deceive citizens, e.g. through

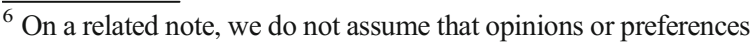
are fixed or stable. They are often based on heuristics and may change over time or in response to new information. The fact that opinions are changed due to social interaction is not worrisome per se, only if brought about through particular "manipulative" means.
}

propaganda, distorted facts about global warming or media censure? Perhaps even less drastic means such as well-designed omnipresent advertisements for charity or public awareness campaigns for global justice projects might suffice. If effective, would not they be less problematic than altering human psychology? Is the practical futility of such a program the only objection?

Likewise, if voter incompetence is the source of the problem, why not tackling it directly by screening for competence and restricting franchise? Affected persons may even conceive exclusion from voting as less burdensome than mandatory enhancement because, as low turnout rates in western democracies indicate, many people might prefer not having a vote and remain who they are to being morally transformed. However, the fact that stripping someone from the right to vote, the quintessential political right, appears as less burdensome than an alternative measure, casts strong doubts on the latter's compatibility with democracy. Indoctrination and disenfranchisement are strikingly at odds with democratic ideals. And if they are, so is moral enhancement.

All strategies to remedy deficiencies on the individual level by remolding citizens against their will through severely manipulative means oppose democratic ideals. At the same time, the possible need to do so lays democracy's inextricable inner contradictions open. One simply cannot have both: popular sovereignty and legitimacy for policies without public support. Moral enhancement cannot provide an escape from the dilemma. But the sheer necessity to alter the electorate is not an argument for the compatibility with democracy. So, to give a conclusive answer to our initial question: A government elected by severely manipulated voters lacks democratic legitimacy. And this applies to governments following Persson and Savulescu's suggestions. However, recall that this does not necessarily imply that such a government lacks any legitimacy: if those who hold power - the people - do not endorse combating global warming and injustice, and if these goals are morally imperative, one may look for other, output-based forms of legitimacy. But this is tantamount to abandoning the democratic project.

\section{Democratic Perspectives and Solutions}

We are at a critical juncture: Do we need more democracy - including citizen participation — or do we need less, curtailing citizens' influence? While moral 
enhancement points in the latter direction, the former might be the more promising and legitimacy preserving direction. We suggest that global injustice and climate change might actually be redressed by strengthening democracy. Some of the biggest shortcomings of current democratic rule might be overcome not by altering the citizens but by expanding the citizenry.

One of the problematic psychological dispositiongeographical parochialism - has tremendous effects on people who happen to live in distant countries. In a globalized world many political (and private) actions have effects ("externalities") on people who are not themselves part of the populace that makes up the demos. The Global South does not have a vote in elections in the US or the EU, although their policies have strong impact on the Global South's fate as bearers of global economic injustice and of the effects of climate change, both of which lead to malnutrition, other health-related problems, even death; to political instability, and we should not forget in these days, to global migration.

Geographical parochialism is problematic for democratic theory if we accept two points. First, the demos cannot itself be determined democratically; it is thus not democratically justified. And, second, a particular demos cannot be justified by mere "blood and soil". As Robert Goodin writes: "There is no principled reason for settling on any of those, in and of themselves. It is arbitrary, from a moral point of view, where we draw the lines on the map. It is arbitrary, from a moral point of view, to whom we happen to feel sentimentally attached or with whom we happen to share a common history or ancestry" [46, p. 48]. Restricting the demos arbitrarily violates an essential democratic idea, and its revitalization can provide a promising solution to the problem: everyone who is affected by a measure should have a say in it: "Everyone who is affected by the decisions of a government should have the right to participate in that government" [47, p. 64]. This principle counts all potentially affected interests equally and has far-ranging implications. Goodin notes:

By embracing all possible worlds, politically, this expansive conception of 'all possibly affected interests' causes the franchise to balloon dramatically and the scope for legitimate exclusions to shrink accordingly. Virtually (maybe literally) everyone in the world - and indeed everyone in all possible future worlds - should be entitled to vote on any proposal or any proposal for proposals. A maximally extensive franchise, virtually (perhaps literally) ignoring boundaries both of space and of time, would be the only legitimate way of constituting the demos to this more defensible version of the 'all possibly affected interests' principle [46, p. 55].

If this version of modern cosmopolitanism sounds too utopian, one might look out for means that help to approximate the ideal global democracy [cf. 48]. One option would be to continue enhancing the collaboration between strong democratic national states, for example in institutions such as the UN, IMF, WTO and the OECD, [cf. 49]. This requires the inclusion of all affected states, not only of a set number of member states. Moreover, many of these institutions - for instance the IMF-will need internal reform in order to yield just policies [for a discussion of cosmopolitanism and multinational collaboration see, 50]. The nascent political idea of global constitutionalism points in the same direction.

Current politics is not only shortsighted with regards to faraway people, but also towards the future. This temporal parochialism of current politics makes progress in fighting anthropogenic climate change notoriously difficult. It is indeed difficult to include future generations in the political process. As the nonexisting cannot speak for themselves, one option to include their interests is to have them represented through a proxy, for example by assigning a certain number of seats in parliament for people who speak on behalf of future generations [51, 52]. These proxies can, for example, be representatives of environmental NGOs. Another option would be the introduction of age conditions under which political power is exercised, for example by introducing a maximum voting age, lowering the minimum voting age, or by making the weight of a person's vote age-sensitive [53]. Such proposals might promote intergenerational justice if it is true that younger people tend to be more concerned with the future [for a discussion, see 54]. Other institutional conditions for the promotion of moral behavior include the creation of an environment of physical and economic security, both internationally and locally, and the reduction of the incidence of infectious disease [cf. 55].

We do not need to decide between these suggestions. Our point is this: the idea of democracy has the theoretical resources to engage with today's mega-problems. Rather than abandoning it in favor of more authoritarian 
models - irrespective of whether they can be called democracies - , the somewhat unfulfilled potential of democracy has to be tapped: Equal influence of everyone affected. Its realization surely requires no less than drastic reforms. And one might well object that the same moral myopia that prevents us from tackling climate change and global injustice will likely prevent the implementation of the principle of equal influence of everyone affected. But before we resort to harsh and undemocratic means such as society-wide moral enhancement, we should take remaining democratic options seriously. Power -not powder-to the people.

Acknowledgments Open access funding provided by University of Salzburg.

Open Access This article is distributed under the terms of the Creative Commons Attribution 4.0 International License (http:// creativecommons.org/licenses/by/4.0/), which permits unrestricted use, distribution, and reproduction in any medium, provided you give appropriate credit to the original author(s) and the source, provide a link to the Creative Commons license, and indicate if changes were made.

\section{References}

1. Persson, I., and J. Savulescu. 2014. Unfit for the Future: The Need For Moral Enhancement. Oxford: Oxford University Press.

2. Persson, I., and J. Savulescu. 2008. The perils of cognitive enhancement and the urgent imperative to enhance the moral character of humanity. Journal of Applied Philosophy 25(3): 162-177.

3. Persson, I., and J. Savulescu. 2012. Moral enhancement, freedom and the god machine. The Monist 95(3): 399-421.

4. Geller, M. 1988. Cogs in the wheel: the formation of Soviet man. New York: Knopf.

5. Cheng, Y. 2009. Creating the New Man"- From Enlightenment Ideals to Socialist Realities. Honolulu: University of Hawai'i Press.

6. J.-J. Rousseau. 2002. The Social Contract: And, The First and Second Discourses. Yale University Press.

7. J. S. Fishkin, Manipulation and Democratic Theory, in Manipulating Democracy: Democratic Theory, Political Psychology, and Mass Media, W. Le Cheminant and J. M. Parrish, Eds. London: Routledge, 2010, pp. 31-40.

8. Coons, C., and M. Weber. 2014. In Introduction: Investigating the Core Concept and Its Moral Status, in Manipulation: Theory and Practice, eds. C. Coons, and M. Weber, 1-16. Oxford: Oxford University Press.

9. A. Barnhill, What is manipulation, in Manipulation: Theory and Practice, C. Coons and M. Weber, Eds. Oxford: Oxford University Press, 2014, pp. 51-72.
10. Buss, S. 2005. Valuing autonomy and respecting persons: manipulation, seduction, and the basis of moral constraints. Ethics 115(2): 195-235.

11. Baron, M. 2003. Manipulativeness. Proc. Addresses Am. Philos. Assoc. 77(2): 37-54.

12. T. Ball, Manipulation: As Old as Democracy Itself (and Sometimes Dangerous), in Manipulating Democracy: Democratic Theory, Political Psychology, and Mass Media, W. Le Cheminant and J. M. Parrish, Eds. London: Routledge, 2010, pp. 41-58.

13. N. Klemp, When Rhetoric Turns Manipulative, in Manipulating Democracy: Democratic Theory, Political Psychology, and Mass Media, W. Le Cheminant and J. M. Parrish, Eds. London: Routledge, 2010, pp. 59-86.

14. Goodin, R.E. 1980. Manipulatory politics. New Haven: Yale University Press.

15. C. Wood, Coercion, Manipulation, Exploitation, in Manipulation: Theory and Practice, C. Coons and M. Weber, Eds. Oxford: Oxford University Press, 2014, pp. 17-50.

16. Douglas, T. 2014. Enhancing moral conformity and enhancing moral worth. Neuroethics 7(1): 75-91.

17. Wiseman, H. 2016. The Myth of the Moral Brain: The Limits of Moral Enhancement. Cambridge, MA: MIT Press.

18. Ehni, H.-J., and D. Aurenque. 2012. On moral enhancement from a Habermasian perspective. Cambridge Quarterly of Healthcare Ethics 21(2): 223-234.

19. Bublitz, C., and R. Merkel. 2014. Crimes against minds: on mental manipulations, harms and a human right to mental selfdetermination. Criminal Law and Philosophy 8(1): 51-77.

20. Lippmann, W. 1998. Public Opinion, reissue. New Brunswick, London: Transaction Publishers.

21. Council of Europe. 2002. Venice Commission, Code of Good Practice in Electoral Matters: Guidelines and Explanatory Report.

22. Faden, R.R., and T.L. Beauchamp. 1986. The history and theory of informed consent. New York: Oxford University Press.

23. Thalberg, I. 1989. Hierarchical analyses of unfree action. In The Inner citadel: essays on individual autonomy, ed. J.P. Christman, 123-136. New York: Oxford University Press.

24. Bublitz, C., and R. Merkel. 2013. Guilty minds in washed brains? Manipulation cases and the limits of neuroscientific excuses in liberal legal orders. In Neuroscience and legal responsibility, ed. N.A. Vincent, 333-372. New York: Oxford University Press.

25. Mele, A. 1991. History and personal autonomy. Canadian Journal of Philosophy 23: 271-280.

26. Fischer, J.M., and M. Ravizza. 1998. Responsibility and control: a theory of moral responsibility. Cambridge. New York: Cambridge University Press.

27. Rawls, J. 2005. A theory of justice, Original edn. Cambridge, MA: Belknap Press.

28. Brettschneider, C. 2007. Democratic Rights: The Substance of Self-Government. Princeton, NJ: Princeton University Press.

29. Dworkin, R. 2011. Justice for hedgehogs. Cambridge, MA: Harvard University Press.

30. Dworkin, R. 1986. Law's Empire. Cambridge, MA: Harvard University Press.

31. Dworkin, R. 2002. Sovereign Virtue: The Theory and Practice of Equality. Cambridge, MA: Harvard University Press. 
32. Pettit, P. 1997. Republicanism: A Theory of Freedom and Government. Oxford. New York: Oxford University Press.

33. Habermas, J. 1975. Legitimation crisis. Boston: Beacon Press.

34. Cohen, J. 1997. Deliberation and democratic legitimacy. In Deliberative Democracy: Essays on Reason and Politics, eds. J. Bohman, and W. Rehg, 67-92. Cambridge, MA: MIT Press.

35. Habermas, J. 1996. Between Facts and Norms: Contributions to a Discourse Theory of Law and Democracy. Cambridge: Polity Press.

36. Gutmann, A., and D. Thompson. 2004. Why Deliberative Democracy? New Jersey: Princeton University Press.

37. Pettit, P. 2004. Depoliticizing democracy. Ratio Juris 17(1): 52-65.

38. Sandel, M. 1996. Democracy's discontent: America in search of a public philosophy. Cambridge, MA: Harvard University Press.

39. Rawls, J. 1997. The idea of public reason. In Deliberative Democracy: Essays on Reason and Politics, eds. J. Bohman, and W. Rehg, 93-144. Cambridge, MA: MIT Press.

40. Shapiro, I. 2003. The state of democratic theory. Princeton: Princeton University Press.

41. Buchanan, A.E. 2004. Political liberalism and social epistemology. Philosophy \& Public Affairs 32(2): 95-130.

42. Taylor, M. 2003. Citizenmaking: the dark side of the formative project. Public Aff. Q. 17(3): 241-252.

43. Fowler, T. 2015. In Defence of state directed enhancement. Journal of Applied Philosophy 32(1): 67-81.

44. Brighouse, H. 1998. Civic education and liberal legitimacy. Ethics 108(4): 719-745.
45. Levy, N. 2007. Neuroethics: Challenges for the twenty-first Century. Cambridge, UK: Cambridge University Press.

46. Goodin, R.E. 2007. Enfranchising all affected interests, and its alternatives. Philosophy \& Public Affairs 35(1): 40-68.

47. Dahl, R.A. 1970. After the Revolution? Authority in a Good Society. New Haven: Yale University Press.

48. Tännsjö, T. 2008. Global Democracy: The Case for a World Government. Edinburgh: Edinburgh University Press.

49. Keohane, R.O., S. Macedo, and A. Moravcsik. 2009. Democracy-enhancing multilateralism. International Organization 63(1): 1-31.

50. Scholte, J.A. 2014. Reinventing global democracy. Eur. J. Int. Relat. 20(1): 3-28.

51. Thompson, D.F. 2005. Democracy in time: popular sovereignty and temporal representation. Constellations 12(2): 245261.

52. Ekeli, K.S. 2009. Constitutional experiments: representing future generations through Submajority rules. Journal of Political Philosophy 17(4): 440-461.

53. Van Parijs, P. 1998. The disfranchisement of the elderly, and other attempts to secure intergenerational justice. Philosophy \& Public Affairs 27(4): 292-333.

54. Kates, M. 2015. Justice, democracy, and future generations. Crit. Rev. Int. Soc. Polit. Philos. 18(5): 508-528.

55. R. Powell and A. E. Buchanan, The Evolution of Moral Enhancement, in The Ethics of Human Enhancement: Understanding the Debate, S. Clarke, J. Savulescu, and C. A. J. Coady, Eds. Oxford: Oxford University Press, forthcoming. 